\title{
CORRELATION BETWEEN CERVICAL MORPHOLOGY, PAIN, FUNCTIONALITY, AND ROM IN INDIVIDUALS WITH CERVICALGIA
}

\author{
CORRELAÇÃO ENTRE MORFOLOGIA CERVICAL, DOR, FUNCIONALIDADE E ADM \\ EM INDIVIIDUOS COM CERVICALGIA
}

\author{
CORRELACIÓN ENTRE MORFOLOGÍA CERVICAL, DOLOR, FUNCIONALIDAD Y ADM \\ EN INDIVIDUOS CON CERVICALGIA
}

\author{
Mateus Alves Aimi, ${ }^{1}$ Eduardo Gonçalves Raupp ${ }^{2}$ Emanuelle Francine Detogni Schmit, ${ }^{2}$ Adriane Vieira, $^{2}$ Cláudia Tarragô Candotti $^{2}$ \\ 1. Universidade Federal do Rio Grande do Sul, School of Physical Education, Physical Therapy, and Dance, Porto Alegre, RS, Brazil. \\ 2. Universidade Federal do Rio Grande do Sul, Post-graduate Program in Human Movement Sciences, Porto Alegre, RS, Brazil.
}

\begin{abstract}
Objective: To verify if there is a correlation between the morphology of the cervical spine curvature, pain intensity, functional disability, and range of motion in individuals with cervicalgia. Methods: Thirty-nine individuals were evaluated using x-rays in the right sagittal plane (Cobb C1-C7 two-line method), visual analogue scale, Neck Disability Index questionnaire, and fleximeter. Descriptive statistical analysis (percentage, mean and standard deviation) and inferential (independent t-test and Pearson product-moment correlation coefficient, $\alpha=0.05$ ) were performed. Results: There were significant correlations, ranging from moderate to high, between functional capacity and pain intensity $(r=0.637, p<0.001)$, and total range of motion $(r=-0.568, p<0.001)$, and extension $(r=-0.610, p<0.001)$, and between pain intensity and range of motion $(r=-0.422, p=0.007)$. Regarding the morphology of the cervical spine curvature, none of the variables showed a significant correlation. Conclusions: Cervical morphology, more specifically related to the curvature in the sagittal plane, does not seem to interfere alone with pain, functionality, and range of motion. In contrast, it is possible to affirm that higher levels of pain generate a smaller range of cervical movement, especially of extension, which, in turn, results in greater functional losses in individuals with neck pain. Level of Evidence II; Prognostic Studies - Investigating the Effect of a Patient Characteristic on the Outcome of Disease.
\end{abstract}

Keywords: Neck Pain; Posture; X Rays.

\section{RESUMO}

Objetivo: Verificar se existe correlação entre a morfologia da curvatura da coluna cervical, a intensidade da dor, a incapacidade funcional e a amplitude de movimento em indivíduos com cenvicalgia. Métodos: Foram avaliados 39 indivíduos, por meio de Raios x no plano sagital direito (método Cobb C1-C7 duas linhas), da escala visual analógica, do questionário Neck Disability Index e de um flexímetro. Foi realizada análise estatística descritiva (porcentagem, média e desvio padrão) e inferencial (teste t independente e coeficiente de correlação produto-momento de Pearson, $\alpha=0,05)$. Resultados: Foram encontradas correlações significativas, que variaram de moderada a alta, entre a incapacidade funcional e a intensidade da dor ( $r=0,637 ; p<0,001)$ e a amplitude de movimento total $(r=-0,568 ; p<0,001)$ e de extensão ( $r=-0,610 ; p<0,001)$; e, entre a intensidade da dor e a amplitude de movimento de extensão $(r=-0,422 ; p=0,007)$. Quanto a morfologia da curvatura da coluna cervical, nenhuma das variáveis apresentou correlação significativa. Conclusões: A morfologia cenvical, relacionada mais especificamente à curvatura no plano sagital, parece não interferir por si só no acometimento álgico, na funcionalidade e na amplitude de movimento. Em contrapartida, é possível afirmar que níveis mais elevados de dor geram uma menor amplitude de movimento cervical, especialmente de extensão, os quais, por sua vez resultam em maiores perdas funcionais, em indivíduos com cervicalgia. Nível de Evidência II; Estudos prognósticos - Investigação do efeito de característica de um paciente sobre o desfecho da doença.

Descritores: Cervicalgia; Postura; Raios x.

\section{RESUMEN}

Objetivo: Verificar si existe correlación entre la morfología de la curvatura de la columna cervical, la intensidad del dolor, la incapacidad funcional y la amplitud de movimiento en individuos con cervicalgia. Métodos: Se evaluaron 39 individuos, por medio de rayos X en el plano sagital derecho (método Cobb C1-C7 dos líneas), de la escala visual analógica, del cuestionario Neck Disability Index y de un flexímetro. Se realizó un análisis estadístico descriptivo (porcentaje, promedio y desviación estándar) e inferencial (prueba t independiente y coeficiente de correlación producto-momento de Pearson, $\alpha=0,05)$. Resultados: Se encontraron correlaciones significativas, que variaron de moderada a alta, entre la incapacidad funcional y la intensidad del dolor $(r=0,637, p<0,001)$ y la amplitud de movimiento total $(r=-0,568, p<0,001)$ y de extensión ( $r$ $=-0,610 ; p<0,001$ ) y entre la intensidad del dolor y la amplitud de movimiento de extensión $(r=-0,422, p=0,007)$. En cuanto a la morfología de la curvatura de la columna cenvical, ninguna de las variables presentó correlación significativa. Conclusiones: La morfología cervical, relacionada más específicamente a la curvatura en el plano sagital, parece no interferir por sí solo en la manifestación álgica, en la funcionalidad y en la amplitud de movimiento. En cambio, es posible afirmar que niveles más elevados de dolor generan una menor amplitud de movimiento cervical, especialmente de extensión, el cual a su vez resulta en mayores pérdidas funcionales en individuos con cervicalgia. Nivel de Evidencia II; Estudios pronósticos - Investigación del efecto de características de un paciente sobre el desenlace de la enfermedad.

Descriptores: Dolor de Cuello; Postura; Rayos X. 


\section{INTRODUCTION}

Cervicalgia is defined as the presence of musculoskeletal pain in the posterior region of the neck, above the shoulder blades, or in the upper dorsal zone. ${ }^{1}$ It is estimated that from 22 to $70 \%$ of the population will have an episode of cervical pain at some time during their life and this is a very common and increasingly frequent problem. ${ }^{1}$ The annual incidence in adults is $14.6 \%$ and women have a higher probability of developing cervical pain and suffering from persistent problems than men.2

In addition to pain in the cervical region, the main complaints from individuals with cervicalgia include reduced range of motion (ROM) and difficulty in completing daily tasks. ${ }^{3}$ Lee, Nicholson, and Adams ${ }^{4}$ suggest that changes in cervical ROM are associated with the development of pain in the region. Additionally, Takeshima et al. ${ }^{5}$ state that the ROM changes in flexion and extension are also associated with the sagittal alignment of the altered cervical spine.

In this sense, recommendations from American guidelines for managing cervical pain ${ }^{1}$ indicate that the diagnosis, prognosis, treatment, and evaluation of the outcomes should be based, among other factors, on the perception of pain and functional disability of the patient and an assessment of the active ROM of the cervical spine. However, despite the high prevalence of dysfunction in the cervical region, to the best of our knowledge, any evidence about existing relationships between morphology, pain, functionality, and ROM is just beginning to come to light. Within this context, the objective of this study was to verify whether there is a correlation between the morphology of the curvature of the cervical spine, pain intensity, functional disability, and range of motion in individuals with cervicalgia.

\section{METHODS}

This observational, cross-sectional study ${ }^{6}$ was approved prior to execution by the Institutional Review Board of the university where it was conducted (CAAE: 55897216.6.0000.5347). The sample size was calculated using $\mathrm{G}^{*}$ Power v.3.1.7 software, using the family of z-tests (Pearson's correlation test), assuming an expected correlation of 0.7 , an alpha of 0.05 , and a power of $90 \%$, yielding a requirement of 25 individuals. To allow for possible sample losses, 39 individuals of both sexes were invited to participate in the study, each of whom voluntarily signed the Informed Consent Form, in compliance with resolution $466 / 12$ of the National Health Council - Brazil. The inclusion criteria were a manifestation of interest in participating in the research, the presence of the cervical pain described, and being between 18 and 60 years of age. And, the exclusion criteria were low quality radiographic images and the existence of any prior surgical spinal intervention.
All the individuals were evaluated on the same day an at the same location in terms of (1) morphology of spinal curvature from X-ray exams; (2) cervical spine flexion and extension ROM; (3) answers to a functional disability questionnaire; and (4) pain profile, determined by means of the visual analog scale. To obtain digital right-profile cervical radiographs in the sagittal plane, the individuals were seated on a bench with shoulders perpendicular to the $x$-ray bucky and instructed to close their eyes, flex and extend the cervical spine two times, and stop in the neutral position in order to standardize the posture for assessment. ${ }^{7}$ Once in this position, the individual was instructed to open their eyes and look straight ahead without moving. The magnitude of the cervical curvature was calculated from the digital radiographs taken using a mathematical routine developed in MATLAB ${ }^{\circledR}$ V. 7.5 software, using the $\mathrm{C} 1-\mathrm{C} 7$ two-line Cobb angles (C1-C7) methodology, considered the gold standard. ${ }^{8}$ After digitization of the anatomical points (center of the anterior and posterior tubercles of $\mathrm{C} 1$ and the anterior inferior and posterior inferior corners of vertebra C7 [Figure 1A]), the Cobb angle of the cervical curvature was obtained (Figure 1B).

The evaluation of the ROM was always performed by the same evaluator. With the individual seated in a chair, a fleximeter (Sanny ${ }^{\circledR}$ - Brazil) was attached to the side of the head with elastic bands (Figure 2A) and the individual was instructed to close their eyes, flex and extend the cervical spine twice, and stop in the neutral position. In this position the fleximeter was zeroed and the individuals instructed to perform maximum cervical flexion (Figure 2B) and extension (Figure $2 \mathrm{C}$ ), the maximum values reached being recorded. ${ }^{1}$ Total ROM was obtained by summing flexion and extension. ${ }^{9}$ It should be noted that there is not yet any consensus in the literature around
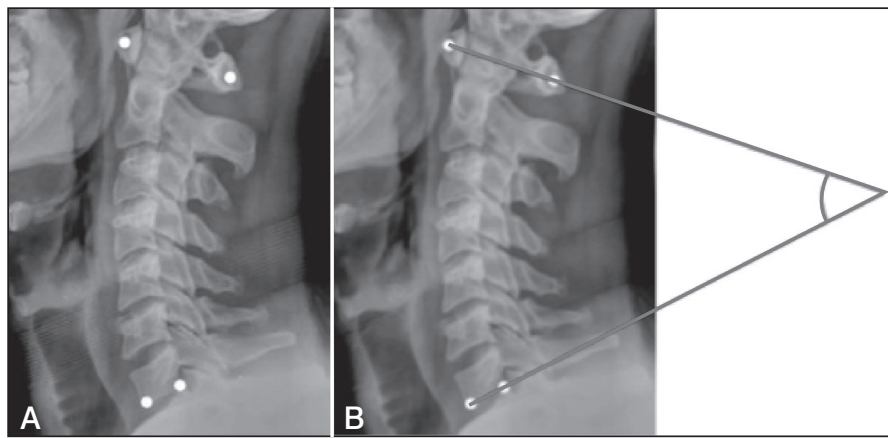

Figure 1. Radiographic analysis: A) marking of the anatomical points in the radiograph; B) obtaining the Cobb $\mathrm{C} 1-\mathrm{C} 7$ angle.

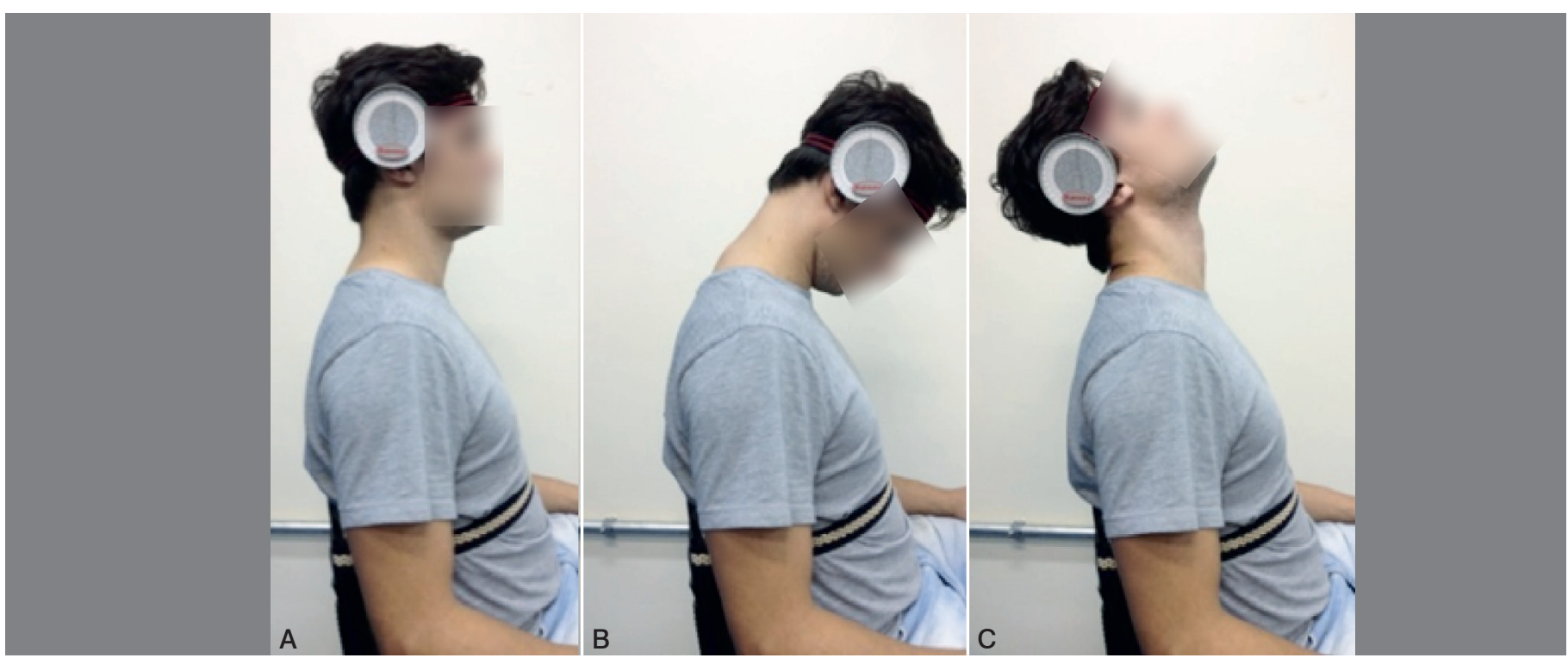

Figure 2. Evaluation of ROM: A) Initial position and attaching the inclinometer; B) Measurement of cervical flexion ROM; C) Measurement of cervical extension ROM. 
normal ROM values of cervical spine flexion/extension, however, according to Magge, ${ }^{10}$ the cervical spine has a flexion range of from $0^{\circ}$ to $80 / 90^{\circ}$ and an extension range of from $0^{\circ}$ to $70^{\circ}$.

Then an evaluation of functional disability was conducted by means of the validated and reproducible Neck Disability Index (NDI) questionnaire ${ }^{11}$ recommended by the American guidelines for cervical pain management, ${ }^{1}$ which consists of 10 sections, including personal care, daily life and leisure activities, among others. Each section is scored on a scale from zero to five, in which five refers to the worst possible state and zero to the lowest level of functional impairment. For analysis, all answers are summed to provide a total score. The interpretation of the final score is as follows: 0 to $4-$ no disability, 5 to 14 - mild disability, 15 to 24 - moderate disability, 25 to 34 - severe disability, and greater than 35 - total disability. ${ }^{12}$

Immediately following the completion of the questionnaire, an evaluation of pain intensity was conducted using the visual analog scale (VAS), which consists of a straight line 10 centimeters $(\mathrm{cm})$ in length where the individual marks their current pain level with an "X", zero being the absence of pain and ten being the worst pain possible. ${ }^{13}$ The VAS results were interpreted using the criteria proposed by Jensen, Chen, and Brugger: ${ }^{14} 0$ to $0.4 \mathrm{~cm}-$ no pain, 0.5 to $4.4 \mathrm{~cm}$ - mild pain, 4.5 to $7.4 \mathrm{~cm}$ - moderate pain, and 7.5 to $10 \mathrm{~cm}$ - severe pain.

For the purpose of comparative analysis, the sample was divided into three groups, taking the morphology of the spinal curvature into account: GR - group with correction, consisting of individuals with Cobb angle less than $35^{\circ}$; GN - group with normal curvature, made up of individuals with Cobb angle between $35^{\circ}$ and $45^{\circ}$; and, GA group with increased curvature, with individuals with Cobb angles greater than $45^{\circ} .{ }^{15}$ Statistical analysis was performed in SPSS v. 20.0 software by means of descriptive (percentage, mean, and standard deviation) and inferential statistics, with $\alpha=0.05$ being adopted. The normality of the data was verified by the Shapiro-Wilk test and the data was distributed normally. A one-way ANOVA with Bonferroni post-hoc test (to analyze possible differences between the groups) and the Pearson product-moment correlation coefficient were applied in order to correlate the variables morphology (Cobb angle), pain intensity, functional disability, and ROM. The correlations ( $r$ ) were classified as very low (between 0.0 and 0.1 ), low (between 0.1 and 0.3 ), moderate (between 0.3 and 0.5 ), high (between 0.5 and 0.7 ), very high (between 0.7 and 0.9 ), and practically perfect (between 0.9 and 1.0 ). ${ }^{16}$

\section{RESULTS}

Thirty-nine (39) individuals were evaluated (61.5\% women, $38.5 \%$ men, age: $36.1 \pm 14.3$ years; weight: $75.4 \pm 18.1 \mathrm{~kg}$, height: $169.7 \pm 9.1 \mathrm{~cm})$, of whom $71.8 \%$ had minimum disability and $61.5 \%$ had mild pain, and, only $41 \%$ were included in the cervical spine correction group. A statistically significant difference was observed in the comparison between the groups only in relation to the variable cervical curvature, in accordance with that expected due to the stratification of the groups. The levels of functional disability, pain, and ROM did not differ significantly between the groups (Table 1).
Statistically significant correlations ranging from moderate to high were found between functional disability and pain intensity $(r=0.637, \mathrm{p}<0.001)$, functional disability and extension ROM ( $r=-$ $0.610 ; p<0.001)$, functional disability and total cervical ROM $(r=-$ $0.568, p<0.001)$, and pain intensity and extension ROM $(r=-0.422$, $p=0.007$ ). These results suggest that the smaller the ROM, especially of extension, the greater the functional disability and the intensity of cervical pain. In terms of the morphology of the curvature of the cervical spine, none of the variables (functional disability, pain intensity, and $\mathrm{ROM}$ ) presented a statistically significant correlation (Table 2).

\section{DISCUSSION}

As already shown, the incidence of cervical pain is higher in women than in men, ${ }^{17}$ a fact that corroborates that observed in this study where there was a higher prevalence among female volunteers. Additionally, it should be noted that cervical pain is becoming a public health issue, directly affecting an increasing number of economically active individuals, ${ }^{18}$ i. e., adults, which aligns with the study sample.

In terms of changes in the alignment of the cervical spine, there are different points of view regarding the vertebral limits to be used for evaluation (C1-C7 and C2-C7). It is well established that the gold standard for evaluation of the cervical spine is radiography using the Cobb method. However, the upper vertebral limit is still unclear and studies are lacking. In spite of this, the combination of limits C1-C7 seems to best represent to lordotic curve in its totality, and, for this reason it was adopted for this study. ${ }^{19,20}$ Several studies point out that changes in sagittal alignment, cervical correction in particular, can result in the acceleration of degenerative processes of the discs and vertebral bodies, and the onset of cervicalgia and headaches. ${ }^{21-23}$ Other authors suggest that asymptomatic individuals with changes in sagittal alignment are probably a normal variation, ${ }^{24-26}$ this being a possible explanation for the fact that in our study we found no difference between the stratified groups in terms of the cervical curvature angle values in relation to the variables of pain intensity, functional disability, and ROM (Table 1).

In addition, our findings corroborate those of Kim et al., ${ }^{27}$ who likewise did not observe any correlation between sagittal alignment of the cervical spine, that is, cervical morphology, and the NDI score,

Table 2. Results of the correlations between the variable cervical curvature, pain intensity, functional disability, and ROM.

\begin{tabular}{c|c|c|c}
\hline Variables & $\begin{array}{c}\text { Cervical } \\
\text { curvature }\end{array}$ & Pain intensity & Functional disability \\
\hline $\begin{array}{c}\text { Cervical } \\
\text { curvature }\end{array}$ & - & $r=0.013, \mathrm{p}=0.940$ & $r=0.025, \mathrm{p}=0.882$ \\
\hline Pain intensity & $r=0.013, \mathrm{p}=0.940$ & - & $r=0.637, \mathrm{p}<0.001^{*}$ \\
\hline Flexion ROM & $r=0.125, \mathrm{p}=0.447$ & $r=0.075, \mathrm{p}=0.940$ & $r=-0.308, \mathrm{p}=0.057$ \\
\hline Extension ROM & $r=0.008, \mathrm{p}=0.959$ & $r=-0.422, \mathrm{p}=0.007^{\star}$ & $r=-0.610, \mathrm{p}<0.001^{*}$ \\
\hline Total ROM & $r=0.068, \mathrm{p}=0.681$ & $r=-0.250, \mathrm{p}=0.124$ & $r=-0.568, \mathrm{p}<0.001$ \\
\hline
\end{tabular}

Key: *statistically significant correlation.

Table 1. Descriptive results of the total sample and separated by groups, and inferential comparison between the group.

\begin{tabular}{|c|c|c|c|c|c|c|}
\hline \multirow{2}{*}{ Variables } & \multirow{2}{*}{$\begin{array}{l}\text { Total sample } \\
\qquad(\mathrm{n}=39)\end{array}$} & \multirow{2}{*}{$\begin{array}{c}\text { GR } \\
(n=16)\end{array}$} & \multirow{2}{*}{$\begin{array}{c}\text { GN } \\
(n=12)\end{array}$} & \multirow{2}{*}{$\begin{array}{c}\text { GA } \\
(n=11)\end{array}$} & \multicolumn{2}{|c|}{$G R \times G N \times G A$} \\
\hline & & & & & $F$ & $\mathrm{p}$ \\
\hline Cervical curvature $\left(\mathrm{Cobb}^{\circ}\right)$ & $38.3 \pm 11.0$ & $27.3 \pm 4.5$ & $40.8 \pm 3.3$ & $51.6 \pm 4.3$ & 118.4 & $<0.001 *$ \\
\hline $\begin{array}{l}\text { Functional disability } \\
\text { (NDI score) }\end{array}$ & $7.9 \pm 6.0$ & $7.9 \pm 7.5$ & $8.3 \pm 5.2$ & $7.5 \pm 4.7$ & 0.048 & 0.953 \\
\hline Total ROM ( $\left.{ }^{\circ}\right)$ & $125.8 \pm 22.7$ & $124.1 \pm 23.3$ & $124.9 \pm 20.6$ & $129.2 \pm 25.7$ & 0.170 & 0.844 \\
\hline
\end{tabular}

Key: GR: group with correction (Cobb $\left.<35^{\circ}\right)$; GN: group with normal curvature $\left(35^{\circ}>\mathrm{Cobb}<45^{\circ}\right)$; GA: group with increased curvature $\left(\mathrm{Cobb}>45^{\circ}\right)$; ${ }^{*}$ statistically significant difference. 
or with the intensity of pain evaluated by the VAS. However, this fact draws attention, since what is commonly observed in the current clinical routine is consistent with greater pain in individuals with correction of the physiological cervical lordotic curvature during static posture, which is directly related to technological advances and the daily use of mobile devices in inappropriate postures for long periods of time. ${ }^{28}$

Nevertheless, it is important to emphasize that, despite the clinically relevant values observed in relation to pain and functional disability, when we classified both the VAS $(4.1 \pm 2.6 \mathrm{~cm})$ and the NDI $(7.9 \pm 6.0)$, the results were mild pain intensity ${ }^{14}$ and mild disability, ${ }^{12}$ respectively. These findings are confirmed by the high correlation observed between the two variables, which suggest that they are directly related to each other (Table 2). Moreover, the mild pain intensity observed may be justified by the fact that they are young people with initial symptoms of disability related to repetitive tasks and inappropriate postures. ${ }^{10,29}$ However, it is important to emphasize that the pain assessment methodology used for including individuals in the sample did not allow us to identify whether the pain was acute and radiating or whether it entailed headache, which could be considered a limitation of the study. But, in spite of this, it is evident that, even in a sample where pain and functional impairment are mild, a significant inverse correlation can be observed between extension ROM, pain intensity, and functional disability.

Regarding ROM, both the total samples and the stratification of groups according to the variable of cervical curvature presented mobility close to the upper limit of normality for flexion and extension, with discretely higher angle values in the group with increased cervical curvature. Ries and Bérzin ${ }^{30}$ state that compensation may be a mechanism required to provide stability for the mandibular and cervical systems. Moreover, according to Ferão and Traebert, ${ }^{31}$ pain is a factor that can interfere with the movement of the cervical spine and prevent total ROM, a situation associated with pressure points in the cervical structures. However, with respect to the non-significant correlation between the variables of pain intensity and ROM in this study, this statement becomes contradictory.
Ernst et al. ${ }^{32}$ evaluated 19 individuals with cervicalgia and found low correlations between flexion and extension ROM of the cervical spine and the NDI indices. However, with respect to high cervical $\mathrm{ROM}$, these same authors found a high inverse correlation between flexion and the headache section of the NDI $(r=-0.62) .^{32}$ Similarly, Kwak et al. ${ }^{33}$ evaluated elderly individuals and did not observe significant correlations between ROM of the cervical spine and functional disability as measured by the NDI. One of the justifications for the non-significant correlation is the low mean score obtained in the NDI (10.5\%), since, according to Cleland et al. ${ }^{34}$ a clinically significant result is defined by an NDI score equal to or greater than $14 \%$. In our study, the mean score obtained in the NDA was 7.9, equivalent to $15.6 \%$, this difference being the possible justification for the significant correlation found between the functional disability and cervical extension ROM variables.

Finally, our findings may contribute to clinical practice, since they can be used to guide decision making in the treatment of patients with cervicalgia, given that it was shown that the morphology of the cervical spine does not correlate to ROM, functional conditions, or intensity of cervical pain. Therefore, studies are necessary to evaluate whether the gain in cervical ROM, particularly of extension, is capable of reducing pain and improving the functionality of individuals with cervicalgia.

\section{CONCLUSIONS}

Cervical morphology, more specifically that related the curvature of the sagittal plane, does not seem to interfere in and of itself with pain, functionality, or ROM. In contrast, it can be stated that higher levels of pain cause less cervical range of motion, especially extension, which in turn results in greater functional loss in individuals with cervicalgia.

All authors declare no potential conflict of interest related to this article.

CONTRIBUTION OF THE AUTHORS: Each author made significant individual contributions to the manuscript. MAA (0000-0003-1667-8409)* and EFDS (0000-0002-5530-2773)* were the main contributors to the preparation of the manuscript. EGR (0000-0003-2716-7065)* recruited the individuals, conducted the evaluations, and contributed to the bibliographical research. EFDS (0000-0002-5530-2773* evaluated the statistical analysis data. AV (0000-0003-3846-0873)* and CTC (0000-0002-8676-9157)* reviewed the manuscript and contributed to the intellectual concept of the study. *ORCID (Open Researcher and Contributor ID).

\section{REFERENCES}

1. Childs JD, Cleland JA, Elliott JM, Teyhen DS, Wainner RS, Whitman JM, et al. Neckpain: clinical practice guidelines linked to the International Classification of Functioning, Disability, and Health from the Orthopaedic Section of the American Physical Therapy Association. J Orthop Sports Phys Ther. 2008;38(9):A1-34.

2. Côté P, Cassidy JD, Carroll LJ, Kristman V. The annual incidence and course of neck pain in the general population: a population-based cohort study. Pain. 2004:112(3):267-73.

3. Cook C, Richardson JK, Braga L, MenezesA, Soler X, Kume P, et al. Cross-cultural adaptation and validation of the Brazilian Portuguese version of the Neck Disability Index and Neck Pain and Disability Scale. Spine (Phila Pa 1976). 2006:31(14):1621-7.

4. Lee H, Nicholson LL, Adams RD. Cervical range of motion associations with subclinical neck pain. Spine (Phila Pa 1976). 2004;29(1):33-40

5. Takeshima T, Omokawa S, Takaoka T, Araki M, Ueda Y, Takakura Y. Sagittal alignment of cervical flexion and extension: lateral radiographic analysis. Spine (Phila Pa 1976). 2002;27(15):E348-55.

6. Gaya A, Garlipp DC, Silva MF, Moreira RB. Ciências do movimento humano: introdução à metodologia da pesquisa. Porto Alegre: Artmed; 2008.

7. Harrison DE, Harrison DD, Colloca CJ, Betz J, Janik TJ, Holland B. Repeatability over time of posture, radiograph positioning, and radiograph line drawing: an analysis of six control groups. J Manipulative Physiol Ther. 2003;26(2):87-98.

8. Harrison DE, Harrison DD, Cailliet R, Troyanovich SJ, Janik TJ, Holland B. Cobb method or Harrison posterior tangent method: which to choose for lateral cervical radiographic analysis. Spine (Phila Pa 1976). 2000;25(16):2072-8.

9. Lantz CA, Chen J, Buch D. Clinical validity and stability of active and passive cervical range of motion with regard to total and unilateral uniplanar motion. Spine (Phila Pa 1976) 1999;24(11):1082-9.

10. Magge DJ. Avaliação Musculoesquelética. 4 ed. São Paulo: Manole; 2005
11. Vernon H, Mior S. The Neck Disability Index: a study of reliability and validity. J Manipulative Physiol Ther. 1991;14(7):409-15.

12. Vernon H. The Neck Disability Index: state-of-the-art, 1991-2008. J Manipulative Physiol Ther. 2008;31(7):491-502.

13. Hawker GA, Mian S, Kendzerska T, French M. Measures of adult pain: Visual Analog Scale for Pain (VAS pain), Numeric Rating Scale for Pain (NRS pain), McGill Pain Questionnaire (MPQ), Short form McGill Pain Questionnaire (SF MPQ), Chronic Pain Grade Scale (CPGS), Short Form 36 Bodily Pain Scale (SF 36 BPS), and measure of Intermittent and Constant Osteoarthritis Pain (ICOAP). Arthritis Care Res. 2011;63(S11):S240-52

14. 14. Jensen MP, Chen C, Brugger AM. Interpretation of visual analog scale ratings and change scores: a reanalysis of two clinical trials of postoperative pain. J Pain. 2003:4(7):407-14

15. Yochum TR, Rowe LJ. Essentials of skeletal radiology. 2th ed. Baltimore: Williams \& Wilkins: 1996

16. Hopkins WG. Correlation coefficient: a new view of statistics. Disponível em: < http://sportsci.org/resource/stats/ $>$. Acesso em: 10 de dezembro de 2016.

17. Fejer R, Kyvik KO, Hartvigsen J. The prevalence of neck pain in the world population: a systematic critical review of the literature. Eur Spine J. 2006;15(6):834-48.

18. Gross AR, Paquin JP, Dupont G, Blanchette S, Lalonde P, Cristie T, et al. Exercises for mechanical neck disorders: a Cochrane review update. Man Ther. 2016;24:25-45

19. Ohara A, Miyamoto K, Naganawa T, Matsumoto K, Shimizu K. Reliabilities of and correlations among five standard methods of assessing the sagittal alignment of the cervical spine. Spine (Phila Pa 1976). 2006:31(22):2585-91.

20. Abelin-Genevois K, Idjerouidene A, Roussouly P, Vital JM, Garin C. Cervical spine alignment in the pediatric population: a radiographic normative study of 150 asymptomatic patients. Eur Spine J. 2014:23(7):1442-8

21. Nagasawa A, Sakakibara T, Takahashi A. Roentgenographic Findings of the Cervical Spine in Tension Type Headache. Headache. 1993;33(2):90-5 
22. Katsuura A, Hukuda S, Saruhashi Y, Mori K. Kyphotic malalignment after anterior cervical fusion is one of the factors promoting the degenerative process in adjacent intervertebral levels. Eur Spine J. 2001:10(4):320-4.

23. Harrison DD, Harrison DE, Janik TJ, Cailliet R, Ferrantelli JR, Haas JW, et al. Modeling of the sagittal cervical spine as a method to discriminate hypolordosis: results of elliptical and circular modeling in 72 asymptomatic subjects, 52 acute neck pain subjects, and 70 chronic neck pain subjects. Spine (Phila Pa 1976). 2004:29(22):2485-92.

24. Gardner G, Moretz Jr WH, Robertson JH, Clark C, Shea Jr JJ. Nonsurgical management of small and intracanalicular acoustic tumors. Otolaryngol Head Neck Surg. 1986;94(3):32833

25. Gay RE. The curve of the cervical spine: variations and significance. J Manipulative Physiol Ther. 1993;16(9):591-4

26. Gore DR, Sepic SB, Gardner GM. Roentgenographic findings of the cervical spine in asymptomatic people. Spine (Phila Pa 1976). 1986;11(6):521-4.

27. Kim JH, Kim JH, Kim JH, Kwon TH, Park YK, Moon HJ.The relationship between neck pain and cervical alignment in young female nursing staff. J Korean Neurosurg Soc. 2015;58(3):231-5.

28. Ning $X$, Huang $Y$, Hu B, Nimbarte AD. Neck kinametics and muscle activity during mobile device operations. Int J Ind Ergon. 2015;48(1):10-5
29. Bevilaqua-Grossi D, Chaves TC, Oliveira AS. Cervical spine signs and symptoms: perpetuating rather than predisposing factors for temporomandibular disorders in women. J Appl Oral Sci. 2007;15(4):259-64.

30. Ries LG, Bérzin F. Cervical pain in individuals with and without temporomandibular disorders Braz J Oral Sci. 2016;6(20):1301-7.

31. Ferão MIB, Traebert J. Prevalence of temporomandibular disfunction in patients with cervical pain under physiotherapy treatment. Fisioter mov. 2008;21 (4):63-70.

32. Ernst MJ, Crawford RJ, Schelldorfer S, Rausch-Osthoff AK, Barbero M, Kool J, et al. Extension and flexion in the upper cervical spine in neck pain patients. Man Ther. 2015;20(4):547-52.

33. Kwak S, Niederklein R, Tarcha R, Hughes $C$. Relationship between active cervical range of motion and perceived neck disability in community dwelling elderly individuals. J Ger Phys Ther. 2005;28(2):54-6.

34. Cleland JA, Fritz JM, Whitman JM, Palmer JA. The reliability and construct validity of the Neck Disability Index and patient specific functional scale in patients with cervical radiculopathy. Spine (Phila Pa 1976). 2006;31(5):598-602. 